\title{
Framing Marijuana in Thai Newspapers: An Analysis of Marijuana Stories in Online News Coverage
}

\author{
Arpapat Indradat
}

\begin{abstract}
While many countries in the world start to legalise marijuana, either for medical or recreational purposes, the Thai government is still considering whether or not to put marijuana off the drug lists. Recently, the government has approved a minor change in the drug law, and poll suggests that Thai people are more open to the legalisation. As media influence and inform the public on specific issue, this study aims to look into how online newspapers in Thailand frame marijuana stories. Using frame analysis as a theoretical background and a method, the top two most-read online Thai newspapers-Thairath and Khaosod-and the most read online English newspaper, Bangkok Post, were chosen for the study. Within the period of 6 months (December 2017 to June 2018), the study found five main frames from 158 marijuana stories: law enforcement on illegal drugs, benefits of marijuana for medical use, legalisation stories worldwide, legalisation process in Thailand and discussion in editorial. Not surprisingly, as marijuana is still considered drugs, more than half of the stories from the study (95 stories) used 'law enforcement on illegal drugs' frame in their reporting. Despite having the least number of news stories, Bangkok Post used other four frames more than the other two newspapers, which indicates that Bangkok Post covered the issue in a wider aspect. Limitations of the study are: the limited period of time and the limited number of the online newspapers. Moreover, as frame affects audience perception on specific issue, this leaves gap for further research where media effects can be looked into. To date, research on how media frames marijuana issue in Thailand has not been done before.
\end{abstract}

Index Terms - frame analysis, media framing, content analysis, newspaper analysis, legalisation of marijuana, marijuana in Thailand.

\section{BACKGROUND}

In 2016, at the UN Special Session of the General Assembly on Drugs (UNGASS), the UN has declared that the war on drug is a failure, it was agreed that the suppression approach had failed completely and different approach should be used instead (Somjittranukit 2017). As a response to failure on the war on drugs, many developed countries such as Canada, Austria, Belgium, Denmark, Czech Republic and France, as well as 30 states in America, have legalised the use of marijuana for medical purposes (Lopez 2018). Legalisation of medical marijuana is on the rise across the western world, and some countries now allow recreational use. In the same way, after the announcement from the UN, the Thai government has

Arpapat Indradat, Ph.D.Lecturer, School of Communication Arts, Bangkok University, Thailand announced that methamphetamines, marijuana and krathom will be taken off the list of drugs in Thailand in the future.

At this moment, Marijuana is still categorised as a Class 5 illegal drug under the 1979 Narcotic Drugs Act and recreational use is still illegal in Thailand, with jail terms of up for five years for possession, cultivation and transportation of up to $10 \mathrm{~kg}$. But the change is now on its way. In December 2017, the Thai government has approved a Narcotics Control Board proposal for farmers to grow hemp or cannabis sativa, in 15 districts of six provinces: Chiang Mai, Chiang Rai, Nan, Tak, Phetchabun and Mae Hong Son. The Thai government supports research on marijuana and its medical and medicinal benefits by approving draft legislation permitting research on the effects of medicinal marijuana on humans. Rangsit university's researchers obtained permission to develop a cannabis extract spray for cancer patients, and it is believed that the research has gone past testing done elsewhere in the world (Parpart 2018). The first legal cannabis company, in cooperation with Maejo university and the Royal Project Foundation, is established under the name The Thai Cannabis Corporation.

On the public side, online movement on marijuana legalisation in Thailand has emerged long before the government's legislation process. The most prominent one is the people behind the Facebook page 'Ganchachon', which was launched 5 years ago. The page is a channel to educate the public on the benefits of marijuana and to organise events and activities. Recently the discussion on marijuana and its benefit has been on the rise. In an online poll asking public opinion on whether the Thai government should legalise marijuana revealed a surprising result as nearly 80 percent of respondents saying "yes", and those who agreed also said that should allow marijuana to be used for both medical and recreational purposes (Asian Correspondent 2016). Several news programs have put the topic of marijuana on their shows. Topics are, for example, Marijuana: from drugs to agriculture crop (Tnamcot 2018), Can marijuana really cure cancer? (Thai PBS 2016), Shall we unlock Ganja? (TNN News 2018), Taken Ganja out of drug list? (Amarin TV 2015). All these examples show a tiny step toward the right direction for the Thai public and this change is the sign to prove that the Thai public are more open toward the drug reform.

It is confirmed that medical marijuana will be used from May 
2019, and Thailand will be the first country in Asia to legalise marijuana for medical purposes. In this long road to the soon-to-be implemented drug law, it is important to see information given to the public on the issue. Since media inform the public on news and events that happen around them, how the media present marijuana issues will have effects on how the public see the issue. The objective of this research is to see how the Thai media, in this study, online newspapers, reported marijuana stories. Up until now, research on how media frames marijuana issue in Thailand has not been done before.

\section{THEORETICAL APPROACHES}

To answer the research question on how marijuana is presented in online newspapers in Thailand, two theoretical approaches are applied. The first approach is mass communication theory. Mass media becomes a new mediator connecting people with social reality so the media has a crucial role in distributing knowledge and information to the public (McQuail 2000). In this study, the issue of marijuana and the legalisation process are presented to the audience through the media, which decides what and how to report. Nevertheless, since the media is a cultural institution with its own interests and rules in shaping the perception of reality, their supply of information could be distorted and so the reliability of the media as purely neutral is questionable (McQuail 2000).

The second theoretical approach is framing theory. Framing is a process where a media constructs and defines social issues for its audience (Nelson \& Oxley 1999). Framing in news is important in shaping public's and the decision maker's knowledge of the world, as it affects the perceived importance of any particular issues by highlighting one, and make some issues appear less important by ignoring them (Ibid.) Several media scholars see 'Framing' as a second-level of agenda setting theory, where news story tell audience on what issue to think about (setting-agenda), and the study on frame is on 'how' to think about the issue (McCombs, Shaw and Weaver (1997). Framing analysis, in mass communication studies, is relatively close to content analysis and discourse analysis, it usually combines qualitative and quantitative methods (Neuendorf 2017). Krippendorff (2004) proposed that as reading is fundamentally qualitative, frame analysis is seen as qualitative even when it results in numerical accounts. This study sees framing theory as both theory and method to explore how online newspapers presented marijuana stories. By looking at constantly emerge frames used to present the issue, the result will indicate the dominant frames used in their reporting of marijuana.

\section{Methodology}

The method of the study is frame analysis on online news coverage. The study chose two most-read Thai online newspapers: Thairath and Khaosod, and the most-read English newspaper in Thailand, Bangkok Post (Similar web 2018). To collect marijuana stories, I searched the keyword ' $\square \square \square \square$ ' or 'Ganja' the common name for marijuana in Thai newspapers, and the word 'marijuana' and 'cannabis' in English newspaper. In total, the study found 158 marijuana stories: 62 stories from Khaosod, 54 stories from Thairath and 42 stories from Bangkok Post. The unit of analysis are headlines and news content and the study time is 6-month period ( $1^{\text {st }}$ December 2017 to $10^{\text {th }}$ June 2018).

At the beginning, I chose two main frames to start out as approximation: Law enforcement frame and Informative frame (other uses of marijuana). I read each news stories and looked for the frames or themes in their reporting, and one news story could be classified under only one frame. However, it became obvious that two frames are not enough and so other specific frames emerged in the process of data gathering. After frame analysis on 158 news stories, a frequency analysis was conducted by counting on the number of frames used in the coverage in order to find the most frequent frame in marijuana stories. A comparative analysis of the three online newspapers was made to determine the similarities and differences between them and to see the trend in reporting on the issue within the period given.

\section{FINDINGS}

Within the period of 6 months, the study found 5 main frames in the reporting of marijuana stories in the selected online newspapers. The frames are: law enforcement on illegal drugs, benefits of marijuana for medical use, legalisation stories worldwide, legalisation process in Thailand and discussion in editorial. As frames are composed with other elements (Van Gorp 2007), it is important to show description of each frames found from the study. For stories to be put under 'law enforcement on illegal drugs' frame, the news feature the stories of possession, allocation, smuggling, and arrestment of marijuana users/ smugglers, as well as the punishment for drug-related crimes in Thailand. For stories to be framed under 'benefits of marijuana for medical use' frame, the news will be informative, focusing on the ongoing research and evidence that marijuana has medical and medicinal benefits. For stories to be categorised within 'legalisation stories worldwide' frame, the news feature global stories on movements, activities, business ventures and legislative procedures of the legalisation around the world. Under the 'legalisation in Thailand' frames, stories focus on the ongoing discussion, debates, as well as announcement from the government of Thailand on the issue. Lastly, 'discussion in editorial' frame features editorial articles or opinion that discusses on the ongoing debate of the legalisation of marijuana in Thailand. 


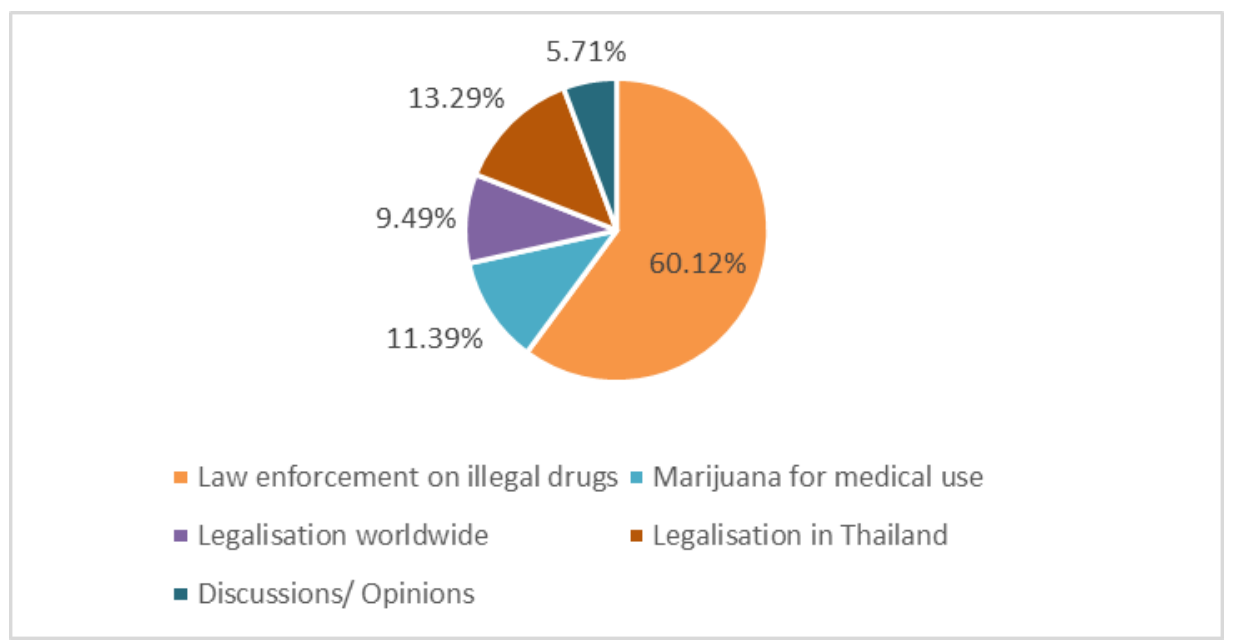

Fig 1: The percentage of frames found from 158 marijuana stories from the three- online newspapers in Thailand within the period of 6 months (December 2017 - June 2018) opinion' on the issue $(5.71 \%$, or 9 news stories).

However, it is interesting to note that while the talk on the

Figure 1 explains the results of the study. The most recurrent frame is 'law enforcement on illegal drugs', more than half of the stories ( $60.12 \%$, or 95 out of 158 stories) in this study were reported using this frame. This result is not so surprising as marijuana is still considered drugs in Thailand so all of the selected newspapers mostly presented the issue from this frame. Other frames are used between 5.71 to $13.29 \%$, five times lesser than the first one. The second most used frame is 'legalisation in Thailand' (13.29\% or 21 news stories), followed by the third most used frame 'marijuana for medical use' $(11.39 \%$, or 18 news stories). The least recurrent frame is 'discussion and change of drug law has been ongoing and evidence from the government -approved research has claimed the benefits of marijuana, the online newspapers did not cover the issue in a more well-rounded manner but focus more on seeing marijuana as 'drugs' and on the law enforcement that follows. Most Thai people still see marijuana as drugs, and, from the findings, the media needs to keep up on reporting on other sides of marijuana issues such as the benefits and the legalisation at a global level in order to inform and prepare the Thai audience on the legalisation of medicinal marijuana which is planned to take place in May 2019.

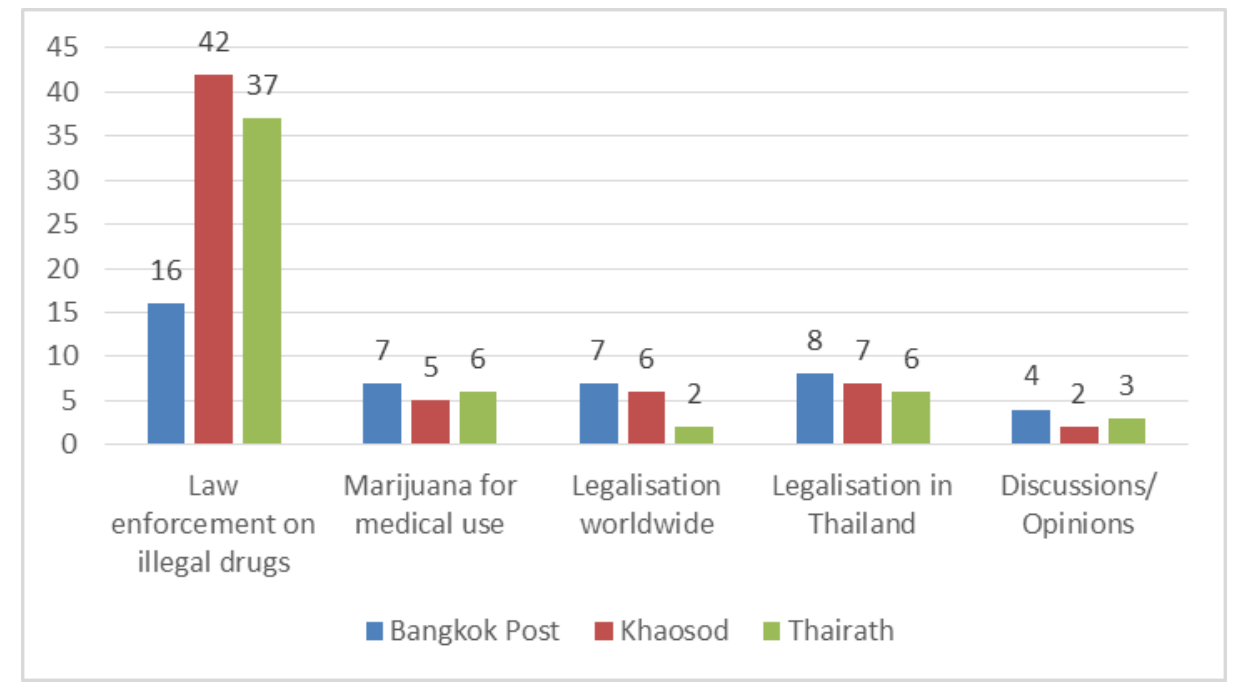

Table I: The number of frames found in marijuana stories from the three online newspapers (158 news stories) within the period of 6 months (December 2017 - June 2018).

Looking closely into the frames in each newspaper, Table 1 illustrated each newspaper and the frames they used to represent marijuana stories. It is clearly seen that all three newspapers used law enforcement on illegal drugs the most. However, despite having the least number of news stories, Bangkok Post used other four frames more than the other two newspapers, which indicates that Bangkok Post covered the issue in a wider aspect. Comparing to other two Thai online newspapers, Bangkok Post covered marijuana issues more by touching all other frames: 8 stories on legalisation in Thailand frame, and 7 stories on legalisation worldwide and 7 stories on marijuana for medical use frame. For Khaosod and Thairath, they covered 
'marijuana for medical use' and 'legalisation in Thailand' at about the same number. While Khaosod reported stories on legalisation worldwide more than other frames, it is surprising to see that Thairath only cover 2 news stories on this frame suggesting that Thairath should inform their readers on what happens around the world on the issue more than they do now.

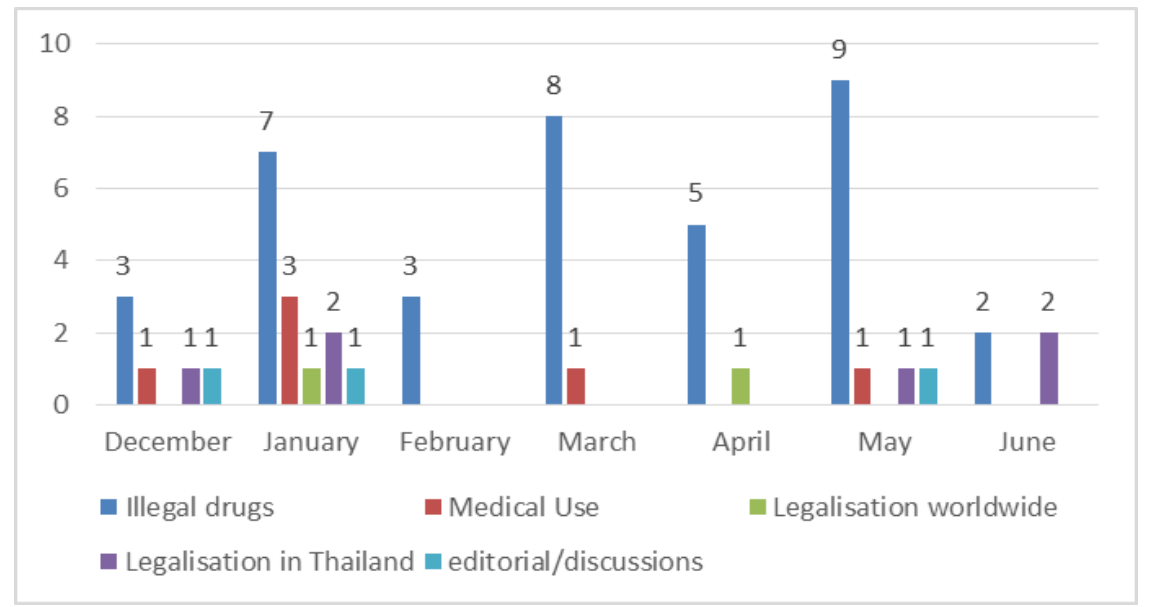

Table II: The Number of different frames found in 54 marijuana stories in Thairath's online news coverage (December 2017 - June 2018).

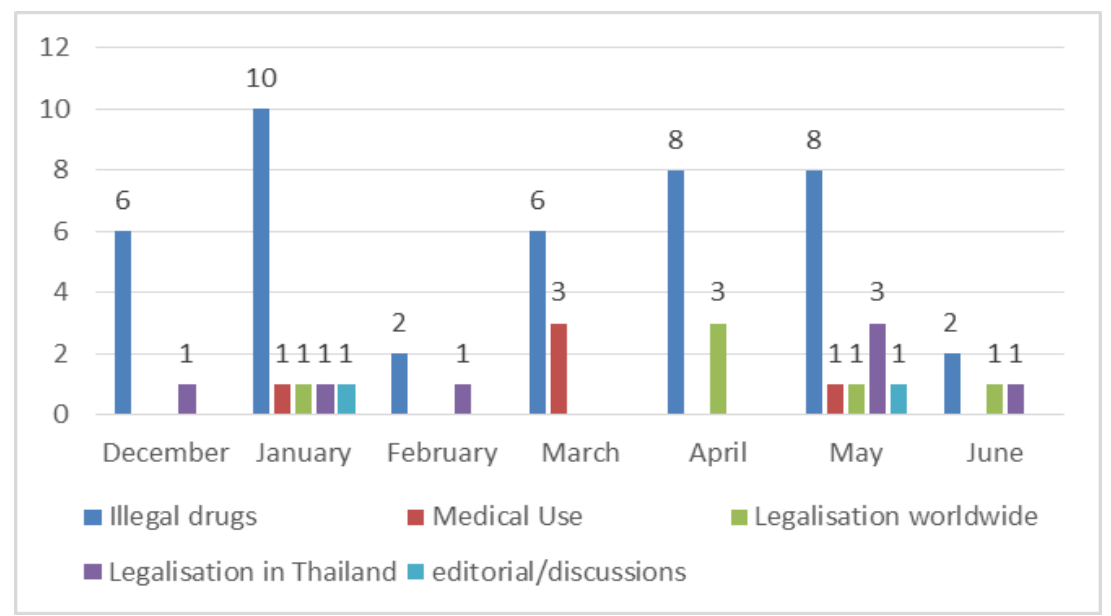

Table III: The Number of different frames found in 62 marijuana stories in Khaosod's online news coverage (December 2017 - June 2018).

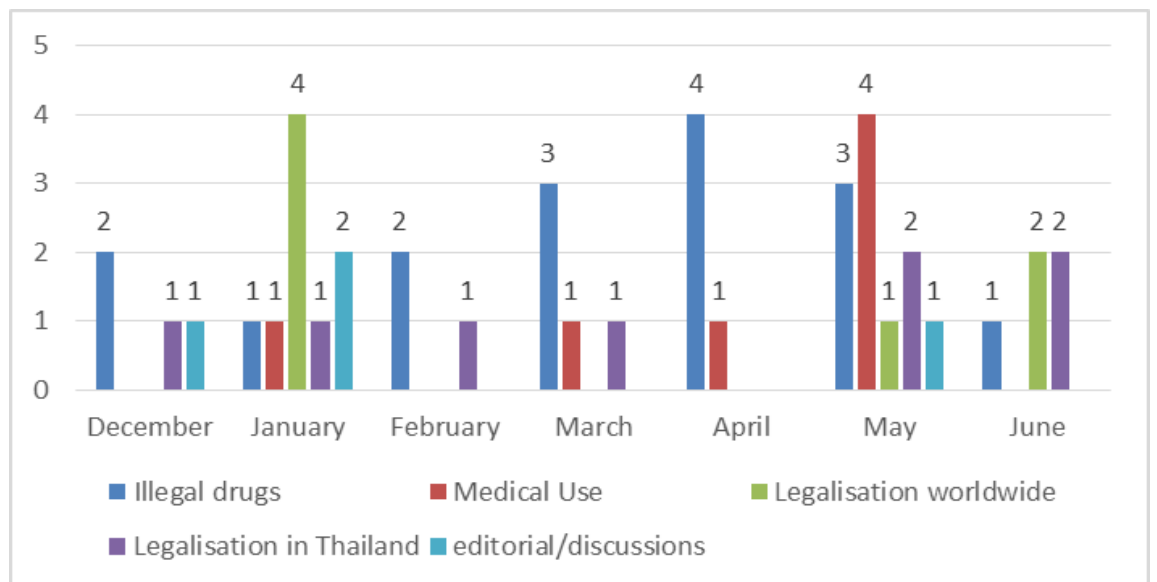

Table IV: The Number of different frames found in 54 marijuana stories in Bangkok Post's online news coverage (December 2017 - June 2018). 
As frames comes in packages and has a relationship with cultural phenomenon (Van Gorp 2007), in this study, the progress of the Thai government in legalisation talk and process. Thus, it is necessary to see the trends in the reporting of marijuana between the three newspapers. I looked into frames used by each newspaper in presenting marijuana stories by month (December 2017 to June 2018). Law enforcement and illegal drugs frame is constantly used throughout the 6-month period in the three newspapers .

For Thairath, as seen in Table 2, the news covered all the frames in December, January and May, and legalisation worldwide frame is used the least during the whole study period. For Khaosod, as seen in Table 3, the news covered all the 5 frames in January and May 2018, but the most distinguished frame is law enforcement, with 42 out of 62 stories. For Bangkok Post, as seen in Table 4, the news covered all 5 frames in January and May, and covered 3 frames in December, March and June. Law enforcement and illegal drugs frame is also the most used, 16 stories out of 42 , but frames such medical use, legalisation worldwide and legalisation in Thailand are covered more than the other two newspapers in 7,7 and 8 news stories accordingly. On the other hand, medical use, legalisation worldwide and legalisation in Thailand frames were featured in Khaosod with 5,6,7 stories and in Thairath with 6,2,6 stories accordingly. For discussion and editorial frame, the study found 4 stories in Thairath, 2 stories in Khaosod and 3 stories in Thairath.

I looked into news stories especially in January and May, and found that marijuana crimes are high in that specific period. At the same time, the report on medical research on marijuana from Office of the Narcotics Control Board (ONCB) and Government Pharmaceutical Organisation (GPO) were announced on the progress in January and May. Thus, enable all of the three news agencies to looked into other aspects of marijuana, resulted in the high number of medical use, legalisation worldwide, legalisation in Thailand news frames in the specific months.

\section{CONCLUSIONS}

To answer the question on 'how' the Thai newspapers presented marijuana stories, results indicated that even in the midst of drug law amendments and the process of legalisation of medical marijuana in Thailand, the selected online newspapers still mostly used law enforcement and illegal drugs frame throughout the study period. The reason could be that 'marijuana' is still considered as drugs according to the Thai law and the Thai public also perceived it as drugs. The study found other frames: benefits of marijuana for medical use, legalisation stories worldwide, legalisation in Thailand, and discussion in editorial. But all these other frames together are still less than stories from the prominent 'law enforcement frame'. In January and May 2018, talks from the government and other related institutions have taken place few times, resulting in the increase in the use of medical use frame and legalisation in Thailand frame in the study. This confirms the fact that media is the mean to keep the public informed about certain issues but the Thai media still need to engage other sides of marijuana stories for the public. Despite having the least number of news stories, Bangkok Post used other four frames more than the other two newspapers, which indicates that Bangkok Post, an English-language newspaper covered the issue in a wider aspect. The legalisation of medical marijuana will take place on May 2019 and before that, I believe the number of other frames will be increased now that the talk and discussion on the legalisation of marijuana in Thailand are on the rise. As news frames can influence the public's attitudes toward marijuana legalisation (Kim 2017), I suggest that the Thai media should, from now on, prepare the public by giving enough and well-rounded information on the benefits for medical and medicinal use of marijuana, and further on the events of legalisation of marijuana worldwide. Most importantly, the Thai media should increase 'discussion and editorial' frame in their coverage as this is a way to give space and to include voices from all sides involved especially the public on the issue.

\section{LIMITATIONS}

Although I believe the findings demonstrated that the chosen method was sufficient to address the research questions in a meaningful way, there are limitations of the study deserved to be mentioned. First, the limited period of time, further study could look into frame analysis within a broader period of time. Secondly, the limited number of the online newspapers, the study only looked into the top two most read online Thai newspapers and one most read online English newspaper, and thus leave gap on the framing of marijuana stories in other newspapers and other forms of media. From this point, further research could explore the new media or social media and how they presented marijuana stories. Moreover, as frame affects audience perception on specific issue, this leaves gap for further research where media effects can be looked into. As Kim (2017) proposed that marijuana experience played an important role in shaping attitudes and thus further study could also include interviews or questionnaires on public opinion on the issues. Despite the limitations, I believe that this study provides opening grounds on how Thai newspapers represented marijuana issues. Future studies could be conducted to provide additional quantitative elements, or to expand to other form of media.

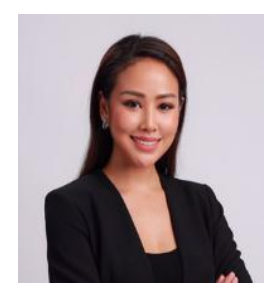

Arpapat Indradat. Ph.D. (Bangkok,
THAILAND).

Received her Doctorate degree in journalism from Bournemouth University, UK in 2015. Currently working as a Lecturer and International Coordinator at School of Communication Arts, Bangkok University. Research interests: journalism, conflict journalism, global affairs, news analysis. 


\section{REFERENCES}

[1] Asian Correspondent (2016). Poll: Should Thailand legalize marijuana? Yes, most say. Asian Correspondent online. 29 August 2016. Available from https://asiancorrespondent.com/2016/08/poll-thailand-lega lize-marijuana-yes-say/\#VtR30wyHOdBDbaj1.99. Accessed 17 May 2018.

[2] Editorial. (2018). Tiny step in drug reform. Bangkok Post online. 23rd May 2018. Available from https:/www.bangkokpost.com/opinion/opinion/1471081/t iny-step-in-drug-reform. Accessed 15th June 2018.

[3] Kim, Hwalbin. 2007. Framing Marijuana: A Study of How US Newspapers Frame Marijuana Legalization Stories and Framing Effects of Marijuana Stories. Thesis. USA: University of South Carolina.

[4] Krippendorff, K., 2004. Content Analysis: An Introduction to Its Methodology (2nd ed.). Thousand Oaks, CA: Sage.

[5] Lopez, G. (2018). The spread of marijuana legalization, explained. Vox news. 26th June 2018.

[6] Availablefrom https://www.vox.com/cards/marijuana-legalization/what-is-medical-mar ijuana. Accessed 28 April 2018.

[7] McCombs, M. E., Shaw, D. L. and Weaver, D. L., 1997. Communication and Democracy. Exploring the Intellectual Frontiers in Agenda-Setting Theory. Mahwah, N.J.: Lawrence Erlbaum

[8] McQuail, D., 2010. Mass Communication Theory. 6 ed. London: Sage.

[9] Nelson, T. \& Oxley, Z. 1999. "Issue Framing Effects on Belief Importance and Opinion," in The Journal of Politics. Vol. 61, no. 4 (Nov., 1999): pp. 1040-1067. https://doi.org/10.2307/2647553

[10] Neuendorf, K., 2017. The Content Analysis Guidebook. (2 ${ }^{\text {nd }}$ edition). SAGE: CA.

[11] Parpart, E. (2018). High time for change. Bangkok Post online. 11 June 2018. Available from. https://www.bangkokpost.com/business/news/1482789/hi gh-time-for-change. Accessed 15th June 2018.

[12] Pisuthipan, A. and Mahavongtrakul, M. (2018). High hopes Thailand inches closer to legalised medical marijuana. In Bangkok Post online. 11st JUNE 2018. Available from https://www.bangkokpost.com/lifestyle/family-and-health/ 1482809/high-hopes. Accessed 15th June 2018.

[13] Ritthikarn, P. (2018) MEDICAL THAI WEED GETS A LAUNCH DATE. Khaosod online ( $4^{\text {th }}$ July 2018)

[14] Available from http://www.khaosodenglish.com/news/2018/07/04/medica 1-thai-weed-gets-a-launch-date/. Accessed 15th June 2018.

[15] Similarweb (2018). Online newspapers ranking (March 2018). Available from. https://www.similarweb.com/top-websites/thailand. Accessed 18 May 2018.

[16] Somjittranukit, K. (2017). Legalization of marijuana in Thailand: possibility or just wishful thinking. Prachatai online. Available from https://prachatai.com/english/node/7063. Accessed 28 April 2018.

[17] Thai PBS. (2016) ตอบโจทย์ ไทยพีบีเอส : ไขข้อข้องใจ "กัญชา" รักษา "มะเร็ง" จริงหรือขายฝัน ...? [online video] $\left(20^{\text {th }}\right.$ April 2016) Available from https://www.youtube.com/watch?v=Ycane4XjsHg. Accessed $5^{\text {th }}$ May 2018.

[18] TNAMCOT. (2018). กัญูชง จากพืชเสพติดสู่พืชเรรษฐึิจในอนาคต [online video] $\left(23^{\text {rd }}\right.$ January 2018) Available from: https://www.youtube.com/watch?v=0ULkKaBvK6k. Accessed 30 ${ }^{\text {th }}$ May 2018.

[19] TNN news (2018) ถึงเวลปลลดล๊อกกัญชา Shall we unlock Ganja? [online video] $\left(5^{\text {th }} \quad\right.$ April 2018) $\quad$ Available https://www.youtube.com/watch?v=UPYPGAqx3xU. Accessed $5^{\text {th }}$ May 2018.

[20] Van Gorp, B., 2007. The Constructionist Approach to Framing: Bringing Culture Back in Journal of Communication. 57(1), (pp. 60 - 78). 